\title{
Karyology of the Atlantic forest rodent Juliomys (Cricetidae): A new karyotype from southern Brazil
}

\author{
Roberta Paresque $^{1 *}$, Alexandre Uarth Christoff ${ }^{2}$ and Valéria Fagundes ${ }^{1}$ \\ ${ }^{1}$ Departamento de Ciências Biológicas, Centro de Ciências Humanas e Naturais, \\ Universidade Federal do Espírito Santo, Vitória, ES, Brazil. \\ ${ }^{2}$ Museu de Ciências Naturais, Universidade Luterana do Brazil, Porto Alegre, RS, Brazil.
}

\begin{abstract}
Juliomys is a small rodent from the family Cricetidae which inhabits the Atlantic forest and forests from Argentina to eastern Brazil. The three species recognized so far have different karyotypes. In this paper, we describe a new karyotype with $2 \mathrm{n}=32, \mathrm{FN}=48$ found in Juliomys specimens from a high-altitude area in the Atlantic forest of southern Brazil. The karyotype was analyzed after $\mathrm{G}$ - and $\mathrm{C}$-banding and silver staining of the nucleolus organizer regions (Ag-NOR) and its G-banding patterns were compared with those of the newly described species Juliomys ossitenuis $(2 n=20, F N=36)$. The $2 n=32$ karyomorph presented peculiar features and was very different from those of the other species of the genus: J. pictipes $(2 \mathrm{n}=36, \mathrm{FN}=34)$, J. rimofrons $(2 \mathrm{n}=20, \mathrm{FN}=34)$ and J. ossitenuis $(2 \mathrm{n}=20$, $\mathrm{FN}=36$ ). Differences were mostly due to centric and tandem fusions, pericentric inversion and loss of heterochromatin. The karyotype represents a powerful tool to differentiate Juliomys species and our data suggest that the karyotype described herein belongs to a new species.
\end{abstract}

Key words: Juliomys, karyotype evolution, J. ossitenuis, comparative G-banding, Ag-NORs.

Received: March 26, 2008; Accepted: October 3, 2008.

The family Cricetidae comprises five subfamilies (Arvicolinae, Cricetinae, Neotominae, Sigmodontinae and Tylomyinae) well-supported by molecular, anatomical and morphological data. Sigmodontinae is the most diverse, harboring nearly 380 species (55\% of the Cricetidae) and 74 genera ( $57 \%$ of the Cricetidae). It is widespread in South America with representatives living throughout humid lowlands of the Amazon forest, Atlantic forest, subtropical savannah and high barren plains and in snow-capped peaks of the Andean Altiplano (Musser and Carleton, 2005).

The systematics and taxonomy of Sigmodontinae is still poorly understood and descriptions of new species (or even genera) have been recurrent (Weksler et al., 2006) due to molecular, morphological or even karyological traits: Akodon paranaensis (Christoff et al., 2000); Juliomys rimofrons (Oliveira and Bonvicino, 2002); Oligoryzomys moojeni and O. rupestris (Weksler and Bonvicino, 2005); Akodon philipmyersi (Pardinãs et al., 2005); and $J$. ossitenuis (Costa et al., 2007). In some cases, new karyo-

Send correspondence to Valéria Fagundes. Laboratório de Genética Animal, Departamento de Ciências Biológicas, Centro de Ciências Humanas e Naturais, Universidade Federal do Espírito Santo, Av. Fernando Ferrari s/n, Goiabeiras, 29075-010 Vitória, ES, Brazil. E-mail: vfagunde@pesquisador.cnpq.br.

${ }^{*}$ Current address: Departamento de Ciências da Saúde, Biológicas e Agrárias, Centro Universitário Norte do Espírito Santo, Universidade Federal do Espírito Santo, São Mateus, ES, Brazil. types were the first step in the identification of the new taxa, as Akodon sp. (Silva and Yonenaga-Yassuda, 1998) and Calomys tocantinsi (Fagundes et al. 2000; Bonvicino et al., 2003).

Juliomys was recently described (González 2000) to accommodate the distinction between J. pictipes (Osgood 1933) and Wilfredomys oenax (Thomas 1928), small rodents characterized by having a tail longer than their head and body, long soft fur, short and broad feet, a pentalophodont molar, an ectolophid present in $\mathrm{M}_{1}$ and $\mathrm{M}_{2}$, a short rostrum in the skull, a wide braincase, and an anteriorly compressed zygomatic bone. The phylogenetic position of the genus in the family is still uncertain and Oliveira and Bonvicino (2002) proposed that Juliomys did not belong to any of Reigs eight tribes (Reig, 1984) according to morphological and DNA sequence data (cytochrome b). Phylogenetic analysis using the DNA sequence of the interphotoreceptor retinoid-binding protein (IRBP) exon placed Juliomys in a distinct clade as incertae sedis (Weksler, 2003; D’Elia et al., 2006).

The three currently recognized species of Juliomys are distributed from Argentina to southeastern Brazil and up to Espírito Santo: J. pictipes (Osgood, 1933) has its type locality in Misiones (Argentina) and occurs in the Atlantic forest from São Paulo to Santa Catarina states in Brazil (Bonvicino and Otazu, 1999); J. rimofrons Oliveira and 
Bonvicino, 2002 is known exclusively from its type locality at Serra da Mantiqueira, municipality of Itamonte, state of Minas Gerais (Brazil); and J. ossitenuis Costa et al., 2007 is found in broadleaf evergreen, semideciduous and montane forests above 800 meters, from Espírito Santo to southern São Paulo, in southeastern Brazil.

Conventional stained karyotypes are easily obtained from live animals and can be used for species distinction in Juliomys (Table 1): $J$. pictipes presents $2 \mathrm{n}=36$ and FN $=34$ (Bonvicino and Otazu, 1999), J. rimofrons has $2 \mathrm{n}=20$ and $\mathrm{FN}=34$ (Oliveira and Bonvicino, 2002), and $J$. ossitenuis has $2 \mathrm{n}=20, \mathrm{FN}=36$ (Costa et al., 2007). In a previous study, the conventionally stained karyotype of $J$. ossitenuis was described and compared with those of $J$. rimofrons, and J. pictipes (Costa et al., 2007). Rearrangements such as centric and tandem fusions and pericentric inversions were involved in the karyotype differentiation within Juliomys. However, comparisons of G-banded karyotypes are required to the adequate identification of chromosome homologies and rearrangements, which, in turn, help in the understanding of the chromosomal evolution in the genus.

In this paper, we describe a new karyotype from Juliomys specimens collected in an area previously not sampled in southern Brazil and we describe for the first time the G- and C-banded karyotypes of Juliomys. In addition, we compared the new karyomorph of Juliomys with that of $J$. ossitenuis and we propose a hypothesis to explain the karyotype evolution in Juliomys.

Cytogenetic analysis was carried out on three males of Juliomys collected at Aparados da Serra National Park, municipality of São Francisco de Paula, state of Rio Grande do Sul, Brazil: MNCU464, MNCU868 and MNCU869, ( $29^{\circ} 29^{\prime} \mathrm{S}$ and $51^{\circ} 30^{\prime} \mathrm{W}$, at $800 \mathrm{~m}$ altitude); and on two males of Juliomys ossitenuis from Caparaó National Park, municipality of Dores do Rio Preto, state of Espírito Santo, Brazil: MBML2784 (20 $46^{\prime} \mathrm{S}$ and $41^{\circ} 81^{\prime} \mathrm{W}$, at $2079 \mathrm{~m}$ altitude) and MBML2783 $\left(20^{\circ} 48^{\prime} \mathrm{S}\right.$ and $41^{\circ} 83^{\prime} \mathrm{W}$, at $1788 \mathrm{~m}$ altitude). The specimens were deposited in the Museu de Ciências Naturais da Universidade Luterana do Brazil (MCNU), Canoas, Rio Grande do Sul, Brazil, and in the Museu de Biologia Prof. Mello Leitão (MBML), Santa Teresa, Espírito Santo, Brazil.

Chromosome preparations were obtained from bone marrow after in vivo injection of a $0.1 \%$ colchicine solution (1 $\mathrm{mL} / 100 \mathrm{~g}$ of body weight). Cells were exposed to $0.075 \mathrm{M} \mathrm{KCl}$ for $25 \mathrm{~min}$ at $37{ }^{\circ} \mathrm{C}$ and subsequently fixed with Carnoy solution (methanol:acetic acid, 3:1). The cell suspensions were spread onto clean slides and air dried. GTG- and CBG-banding and Ag-NOR staining were performed according to Seabright (1971), Sumner (1972) and Howell and Black (1980), respectively. At least 20 metaphases per individual were analyzed to establish the diploid number (2n), the number of autosomal arms (FN) and the distribution pattern of the silver stained nucleolus organizer regions (Ag-NORs).

We found a new karyotype with $2 \mathrm{n}=32$ and $\mathrm{FN}=48$, with one pair of large submetacentrics (pair 1), eight pairs of biarmed autosomes with gradual variation in size (pairs 1-9) and six pairs of acrocentrics (pairs 10-15). The X chromosome was a large submetacentric (larger than chromosome 2), clearly distinct from the autosomes. The $\mathrm{Y}$ was a medium acrocentric, similar in size to chromosome 10 (Figure 1a). G-banding allowed the precise identification of all chromosome pairs (Figure 1c). C-banding revealed small blocks of constitutive heterochromatin at the pericentromeric regions of all autosomes, except for pair 1. Additional segments of heterochromatin were distally located in the long arms of pairs 6,9 and 10 . The $\mathrm{X}$ chromosome is entirely heterochromatic, except the distal long arm, as was the entire $\mathrm{Y}$ chromosome (Figure 1e). Four chromosome pairs had telomeric Ag-NORs (biarmed pairs 2 and 8; and acrocentric pairs 10 and 12). Three to seven Ag-NORs were observed per metaphase. Pairs 2, 8 and 12 showed a high frequency ( $80 \%-95 \%)$ of active NORs on the telomeres of the long arms of both homologues (2q, 8q, and 12q). Most metaphases only had Ag-NORs at one homologue of pair $10(10 q)$, which was less frequently labeled $(40 \%-45 \%)$ than the other NORs (Figure 1g). We found inter and intraindividual variability of Ag-NORs.

Juliomys ossitenuis had $2 \mathrm{n}=20$ and $\mathrm{FN}=36$ with all biarmed chromosomes, except for the acrocentric Y chromo-

Table 1 - Karyotypes of Juliomys species.

\begin{tabular}{|c|c|c|c|c|c|c|c|c|}
\hline \multirow[t]{2}{*}{ Species } & \multirow[t]{2}{*}{$2 n$} & \multirow[t]{2}{*}{$\mathrm{FN}$} & \multicolumn{2}{|c|}{ Autosomes ${ }^{1}$} & \multirow[t]{2}{*}{$\mathrm{X}^{2}$} & \multirow[t]{2}{*}{$\mathrm{Y}^{2}$} & \multirow[t]{2}{*}{ Locality $^{3}$} & \multirow[t]{2}{*}{ References } \\
\hline & & & M & A & & & & \\
\hline J. pictipes & 36 & 34 & - & 17 & A & $\mathrm{A}$ & $\mathrm{SP}, \mathrm{SC}$ & González, 2000 \\
\hline J. rimofrons & 20 & 34 & 8 & 1 & SM & SM & RJ & Oliveira and Bonvicino, 2002 \\
\hline J. ossitenuis & 20 & 36 & 9 & - & M & A & SP, ES, RJ, MG & Costa et al., 2007; present report \\
\hline Juliomys sp. & 32 & 48 & 9 & 6 & SM & A & RS & Present report \\
\hline
\end{tabular}

$2 \mathrm{n}=$ diploid number; $\mathrm{FN}=$ fundamental number.

${ }^{1} \mathrm{M}=$ metacentric/submetacentric, $\mathrm{A}=$ acrocentric.

${ }^{2} \mathrm{M}=$ metacentric, $\mathrm{SM}=$ submetacentric, $\mathrm{A}=$ acrocentric.

${ }^{3}$ States of Brazil: $\mathrm{SP}=$ São Paulo, $\mathrm{SC}=$ Santa Catarina, RJ $=$ Rio de Janeiro, ES = Espírito Santo, RS = Rio Grande do Sul and MG $=$ Minas Gerais 


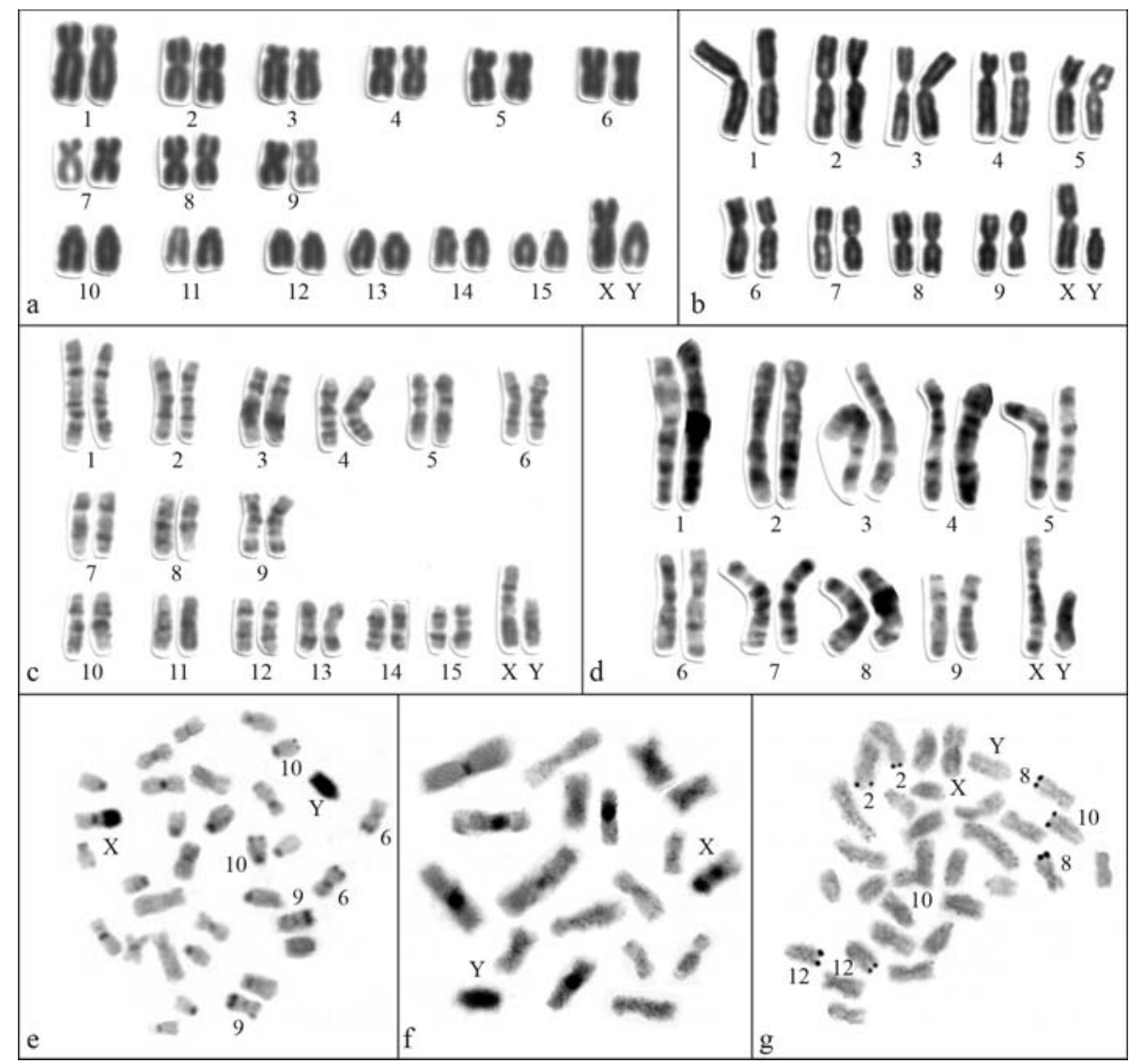

Figure 1 - Karyotypes of ( $\mathrm{a}, \mathrm{c}, \mathrm{e})$ Juliomys $\mathrm{sp}(2 \mathrm{n}=32 ; \mathrm{NF}=48)$ and of (b, d, f) J. ossitenuis $(2 \mathrm{n}=20 ; \mathrm{FN}=36)$ after: (a-b) conventional staining; (c-d) G-banding and (e-f) C-banding; (g) nucleolus organizer regions (Ag-NORs) in Juliomys sp $(2 \mathrm{n}=32, \mathrm{FN}=48)$. The numbers indicate the NOR-bearing chromosomes.

some (as previously described in Costa et al., 2007 and illustrated in Figure 1b). The G-banding patterns are presented for the first time (Figure 1d) and the C-banding revealed constitutive heterochromatin at the centromeric region of most autosomes, in the long arm of the $\mathrm{X}$ and in the entire $\mathrm{Y}$ chromosome (Figure 1f). Multiple telomeric Ag-NORs were observed in five pairs: in the long arms of pairs 2 and 4 ( $2 q$ and $4 q)$, in the short arm of pair $3(3 p)$, and in the short arms of two medium biarmed pairs, not precisely identified, but probably pairs 5 and 6 (data not shown).

The comparative G-banding analysis (Figure 2) revealed homologies between whole chromosome arms of $J$. ossitenuis (JOS) and the new karyotype of Juliomys (JSP). Centric and tandem fusions, as well as pericentric inversions, frequently accounted for the differences between these karyotypes. Two chromosome pairs were completely conserved in the two species: the large submetacentric JSP1 showed complete correspondence with the metacentric JOS2, as was also the case for the medium submetacentrics JSP2 and JOS6. These homeologies were confirmed by the Ag-NOR location in the short arms of JSP2 and its homeologous JOS6. Four large biarmed JOS chromosomes corresponded to eight small JSP chromosomes. A pericentric inversion could explain the difference between the medium submetacentric JSP4 and the long arm of JOS1, while the acrocentric JSP14 corresponded to the short arm of JOS1. A pericentric inversion in the medium submetacentric JSP5 followed by a centric fusion with the acrocentric JSP15 would explain their correspondence with the long and short arm of the large submetacentric JOS3, respectively. A centric fusion between the acrocentrics JSP12 and JSP13 would account for their correspondence with the short and long arms of JOS5, respectively. Almost the entire JSP9 (except for the distal positive G-band in the long arm) corresponded to the short and proximal long arm of JOS4. The remaining portion of JOS4 corresponded to JSP10. The missing positive G- band of JSP9 corresponded to heterochromatin, as revealed by C-banding (Figure 1e). Thus, the loss of the telomere and heterochromatin of JSP 9 and of the centromere and telomere of JSP10, followed by the tandem fusion of JSP9 with JSP10 would have originated JOS4 and the centromeres of JSP9 and JOS4 should thus be homologous.

A comparative karyotypic analysis between Juliomys $\mathrm{sp}(2 \mathrm{n}=32, \mathrm{FN}=48)$ and $J$. pictipes $(2 \mathrm{n}=36, \mathrm{FN}=34)$ based solely on conventional staining suggested that the complements differed by at least one centric fusion (CF) and eight pericentric inversions (PI). The karyotype of $J$. 


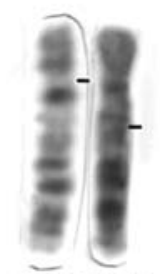

JSP1 JOS2

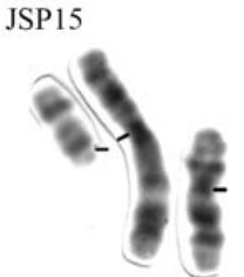

JOS3 JSP5

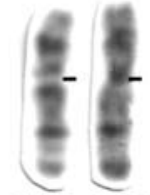

JSP2 JOS6

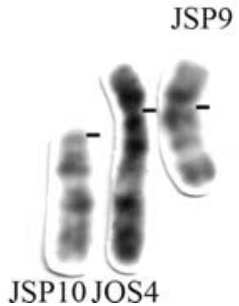

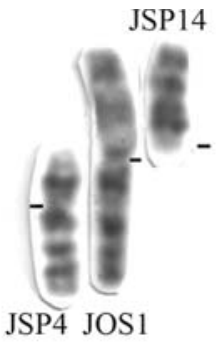

JSP12

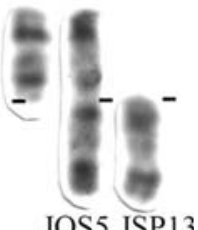

Figure 2 - Comparison of the G-banded chromosomes of Juliomys ossitenuis (JOS) and of Juliomys sp (JSP). The bars indicate centromere positions.

ossitenuis (with nine biarmed chromosome pairs) differs from that of $J$. pictipes (with 17 acrocentric pairs) by at least eight CFs plus one PI, while the complements of $J$. ossitenuis and $J$. rimofrons (eight biarmed and one acrocentric pair) differ by one PI. We thus suggest that eight $\mathrm{CFs}$ were involved in the karyotypic differentiation of Juliomys pictipes $(2 \mathrm{n}=36, \mathrm{FN}=34$, Bonvicino and Otazu, $1999)$ and Juliomys rimofrons $(2 \mathrm{n}=20, \mathrm{FN}=34$, Oliveira and Bonvicino, 2002).

The analyses of the karyotypes of Juliomys indicate that centric and tandem fusions plus pericentric inversions were the most frequent rearrangements involved in the karyotypic differentiation. Comparative G-banding analysis allowed us to conclude that the new karyotype of Juliomys sp and that of J. ossitenuis differed by centric fusions and by some complex rearrangements (tandem fusions, pericentric inversions, loss of heterochromatin). Similar chromosome rearrangements seem to have been involved in the karyotypic differentiation between J. pictipes and $J$. rimofrons.

The rearrangements between the karyotypes of different species are complex and involve transposition of whole chromosome segments, loss of chromosome segments and centromeres, as well as centric and tandem fusions. We thus believe that such rearrangements are enough to prevent individuals with different karyotypes from crossbreeding, acting as an effective postzygotic reproductive barrier. A similar mechanism has been documented in two cryptic and sympatric species of sigmodontine rodents: Akodon cursor (Winge, 1887) $(2 \mathrm{n}=14-16)$ and $A$. montensis Thomas, $1913(2 \mathrm{n}=24)$. Although there is almost complete correspondence between the chromosome arms of the two species which differ by pericentric inversion and tandem fusions (Fagundes et al., 1997), hybrids are not viable (Yonenaga et al., 1975). Moreover, speci- mens of Juliomys with different karyotypes are usually associated with different and disrupt geographic distributions, reinforcing their inability to crossbreed.

In a phylogenetic analysis based on the mitochondrial cytochrome b gene, Costa et al. (2007) concluded that each species of Juliomys could be grouped as a monophyletic clade with 10\%-14\% of divergence among them and each of these species presented a distinctive karyotype. Previous reports had already suggested that species-specific karyotypes were a characteristic of the genus Juliomys (Bonvicino and Otazu, 1999; Oliveira and Bonvicino, 2002).

In summary, the karyological uniqueness allied to the disruptive geographic distribution of the Juliomys specimens from southern Brazil herein studied indicate that it is a new species. Additional morphological and molecular studies are required for the formal species description and for conclusions about its phylogenetic position.

Costa et al. (2007) emphasized the urgent need for large scale collecting of small mammals even in supposedly "well-known" areas such as southeastern Brazil since biodiversity explorations in South America still frequently lead to the discovery of new taxa and the rediscovery of rare species (Percequillo et al., 2004; Emmons and Patton, 2005; Weksler and Bonvicino, 2005). Species of Juliomys are never among the most common taxa at a given locality (Pardiñas et al., 2005) and the largest series from a single site consists of just 11 (J. pictipes) or 28 (Juliomys ossitenuis) specimens. The Atlantic forest is one of the top biodiversity hotspots and it has been suffering from human induced habitat loss and fragmentation. Adequate efforts to catalog the biodiversity of this biome using ecological, morphological, molecular or karyological traits are vital for its conservation.

\section{Acknowledgments}

We thank Emerson Monteiro Vieira (UNISINOS) for collecting some of the specimens. This work was supported by the "Programa Taxonomia" of the Conselho Nacional de Desenvolvimento Científico e Tecnológico (CNPq), Coordenação de Aperfeiçoamento de Pessoal de Nível Superior (CAPES), Critical Ecosystem Partnership Fund (CEPF) and Fundação de Amparo à Pesquisa do Espírito Santo (FAPES). Collecting permits were provided by the Instituto Brasileiro do Meio Ambiente e dos Recursos Naturais Renováveis (IBAMA). We thank the Parque Nacional do Caparaó administrative staff for assistance and logistic support during fieldwork in 2006; and L.A. Baião, N.B. Thomazini, M.X. Machado, and J.A.S. Gomes for helping with the chromosome preparations.

\section{References}

Bonvicino CR, Lima JFS and Almeida FC (2003) A new species of Calomys Waterhouse (Rodentia, Sigmodontinae) from the Cerrado of Central Brazil. Rev Bras Zool 20:301-307. 
Bonvicino CR and Otazu I (1999) The Wilfredomys pictipes (Rodentia, Sigmodontinae) karyotype with comments on the karyosystematics of Brazilian Thomasomyini. Acta Theriol 44:329-332.

Costa LP, Pavan SE, Leite YLR and Fagundes V (2007) A new specie of Juliomys (Mammalia, Rodentia, Cricetidae) from the Atlantic forest of southeastern Brazil. Zootaxa 1463:2137.

Christoff AU, Fagundes V, Sbalqueiro IJ, Mattevi MS and Yonenaga-Yassuda Y (2000) Description of a new species of Akodon (Rodentia, Sigmodontinae) from Southern Brazil. J Mammal 81:838-851.

D’Elía G, Luna L, González EM and Patterson BD (2006) On the Sigmodontinae radiation (Rodentia, Cricetidae): An appraisal of the phylogenetic position of Rhagomys. Mol Phylogenet Evol 38:558-564.

Emmons LH and Patton JL (2005) A new species of Oryzomys (Rodentia, Muridae) from Eastern Bolivia. Am Mus Novit 3478:1-26.

Fagundes V, Scalzi-Martin JM, Sims K, Hozier J and YonenagaYassuda Y (1997) ZOO-FISH of a microdissection DNA library and G-banding patterns reveal the homeology between the Brazilian rodents Akodon cursor and Akodon montensis. Cytogenet Cell Genet 78:224-228.

Fagundes V, Sato Y, Silva MJJ, Rodrigues F and YonenagaYassuda Y (2000) A new species of Calomys (Rodentia, Sigmodontinae) from Central Brazil identified by its karyotype. Hereditas 133:195-200.

González EM (2000) Un nuevo género de roedor sigmodontino de Argentina y Brasil (Mammalia, Rodentia, Sigmodontinae). Com Zool Mus Hist Nat Mont 12:1-12.

Howell WM and Black DA (1980) Controlled silver staining of nucleolus organizer regions with a protective colloidal developer: A 1-step method. Experientia 36:1014-1015.

Musser GG and Carleton MD (2005) Superfamily Muroidea. In: Wilson DE and Reeder DM (eds) Mammal Species of the World. Johns Hopkins University Press, Baltimore, pp 8941531 .
Oliveira JA and Bonvicino CR (2002) A new species of sigmodont rodent from the Atlantic Forest of Eastern Brazil. Acta Theriol 47:307-322.

Pardinãs UFJ, D'Elia G, Cirignoli SN and Suareza P (2005) New species of Akodon (Rodentia, Cricetidae) from the northern Campos grasslands of Argentina. J Mammal 86:462-474.

Percequillo AR, Gonçalves PE and Oliveira JA (2004) The rediscovery of Rhagomys rufescens (Thomas, 1886), with a morphological redescription and comments on its systematic relationships based on morphological and molecular (cytochrome $b$ ) characters. Mamm Biol 69:238-257.

Reig OA (1984) Geographic distribution and evolutionary history of South American muroids, Cricetidae, Sigmodontinae. Rev Bras Genet 7:333-365.

Seabright M (1971) A rapid technique for human chromosomes. Lancet 2:971-972.

Sumner AT (1972) A simple technique for demonstrating centromeric heterochomatin. Exp Cell Res 75:304-306.

Silva MJJ and Yonenaga-Yassuda Y (1998) Karyotype and chromosomal polymorphism of an undescribed Akodon from Central Brazil, a species with the lowest diploid chromosome number in rodents. Cytogenet Cell Genet 81:46-50.

Weksler M (2003) Phylogeny of Neotropical oryzomyine rodents (Muridae, Sigmodontinae) based on the nuclear IRBP exon. Mol Phylogenet Evol 29:331-349.

Weksler M and Bonvicino CR (2005) Taxonomy of pigmy rice rats (genus Oligoryzomys (Rodentia, Sigmodontinae) of the Brazilian Cerrado, with the description of two new species. Arq Mus Nac Rio de Janeiro 63:113-130.

Weksler M, Percequillo AR and Voss RS (2006) Ten new genera of oryzomyine rodents (Cricetidae, Sigmodontinae). Am Mus Novit 3537:1-29.

Yonenaga Y, Kasahara S, Almeida EJC and Peracchi AL (1975) Chromosomal banding patterns in Akodon arviculoides $(2 \mathrm{n}$ $=14)$, Akodon sp. $(2 \mathrm{n}=24,25)$, and two male hybrids with 19 chromosomes. Cytogenet Cell Genet 15:388-399.

Associate Editor: João S. Morgante

License information: This is an open-access article distributed under the terms of the Creative Commons Attribution License, which permits unrestricted use, distribution, and reproduction in any medium, provided the original work is properly cited. 